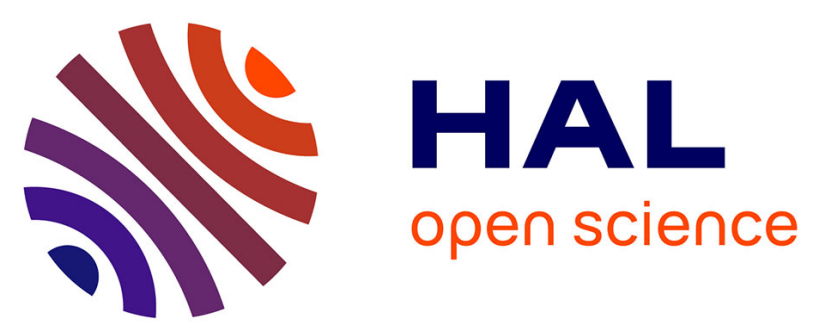

\title{
INFLUENCE OF HCV GENOTYPE 1 SUBTYPES ON THE VIRUS RESPONSE TO PEG INTERFERON ALPHA-2a PLUS RIBAVIRIN THERAPY
}

Florence Nicot, Laurent Alric, Karl Barange, Sophie Métivier, Jean-Michel Dramard, Jean-Marc Combis, Bernard Castan, Jean-Jacques Meurisse, Jean-Louis Payen, Daniel Garipuy, et al.

\section{To cite this version:}

Florence Nicot, Laurent Alric, Karl Barange, Sophie Métivier, Jean-Michel Dramard, et al.. INFLUENCE OF HCV GENOTYPE 1 SUBTYPES ON THE VIRUS RESPONSE TO PEG INTERFERON ALPHA-2a PLUS RIBAVIRIN THERAPY. Journal of Medical Virology, 2011, 83 (3), pp.437. 10.1002/jmv.21976 . hal-00610731

\section{HAL Id: hal-00610731 \\ https://hal.science/hal-00610731}

Submitted on 24 Jul 2011

HAL is a multi-disciplinary open access archive for the deposit and dissemination of scientific research documents, whether they are published or not. The documents may come from teaching and research institutions in France or abroad, or from public or private research centers.
L'archive ouverte pluridisciplinaire HAL, est destinée au dépôt et à la diffusion de documents scientifiques de niveau recherche, publiés ou non, émanant des établissements d'enseignement et de recherche français ou étrangers, des laboratoires publics ou privés. 


\section{INFLUENCE OF HCV GENOTYPE 1 SUBTYPES ON THE VIRUS RESPONSE TO PEG INTERFERON ALPHA-2a PLUS RIBAVIRIN THERAPY}

\begin{tabular}{|c|c|}
\hline Journal: & Journal of Medical Virology \\
\hline Manuscript ID: & JMV-10-2019.R1 \\
\hline Wiley - Manuscript type: & Research Article \\
\hline $\begin{array}{r}\text { Date Submitted by the } \\
\text { Author: }\end{array}$ & 24-Sep-2010 \\
\hline Complete List of Authors: & $\begin{array}{l}\text { Nicot, Florence; Hospital, Virology Laboratory } \\
\text { Alric, Laurent; Toulouse University Hospital, Medecine Interne } \\
\text { Barange, Karl; Toulouse University Hospital, Gastroenterology } \\
\text { Métivier, Sophie; Toulouse University Hospital, Gastroenterology } \\
\text { Dramard, Jean-Michel; Val d'Ariège Hospital, Gastroenterology } \\
\text { Combis, Jean-Marc; Ambroise Paré Cinic, Gastroenterology } \\
\text { Castan, Bernard; Hospital, General Medicine } \\
\text { Meurisse, Jean-Jacques; Hospital, Gastroenterology } \\
\text { Payen, Jean-Louis; Hospital, Internal Medicine } \\
\text { Garipuy, Daniel; Ducuing Hospital } \\
\text { Desmorat, Hervé; Polyclinique du Parc } \\
\text { Peron, Jean-Marie; Toulouse University hospital, Hepato-gastro- } \\
\text { enterology } \\
\text { Thebault, Sophie; Toulouse University Hospital, Internal Medicine } \\
\text { Morin, Thierry; Bigorre Hospital, Gastroenterology } \\
\text { RENOU, Christophe; Hopital, Hepatology } \\
\text { Barel, Pierre; Hospital } \\
\text { Guérin, Bruno; Hospital, Internal Medicine } \\
\text { Imbert, Yves; Hospital, Internal Medicine } \\
\text { Sire, Stéphane; Hospital, Gastroenterology } \\
\text { Sauné, Karine; Toulouse University Hospital, Laboratory of Virology } \\
\text { Chatelut, Etienne; Institut Claudius Regaud, EA3035 } \\
\text { Izopet, Jacques; CHU DE TOULOUSE, VIROLOGIE }\end{array}$ \\
\hline Keywords: & Hepatitis C, HCV subtype, RBV concentration \\
\hline
\end{tabular}

\section{SCHOLARONE \\ Manuscripts}




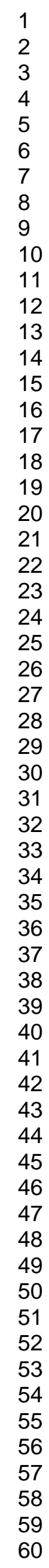

John Wiley \& Sons 
1 Table I: Patient characteristics at inclusion

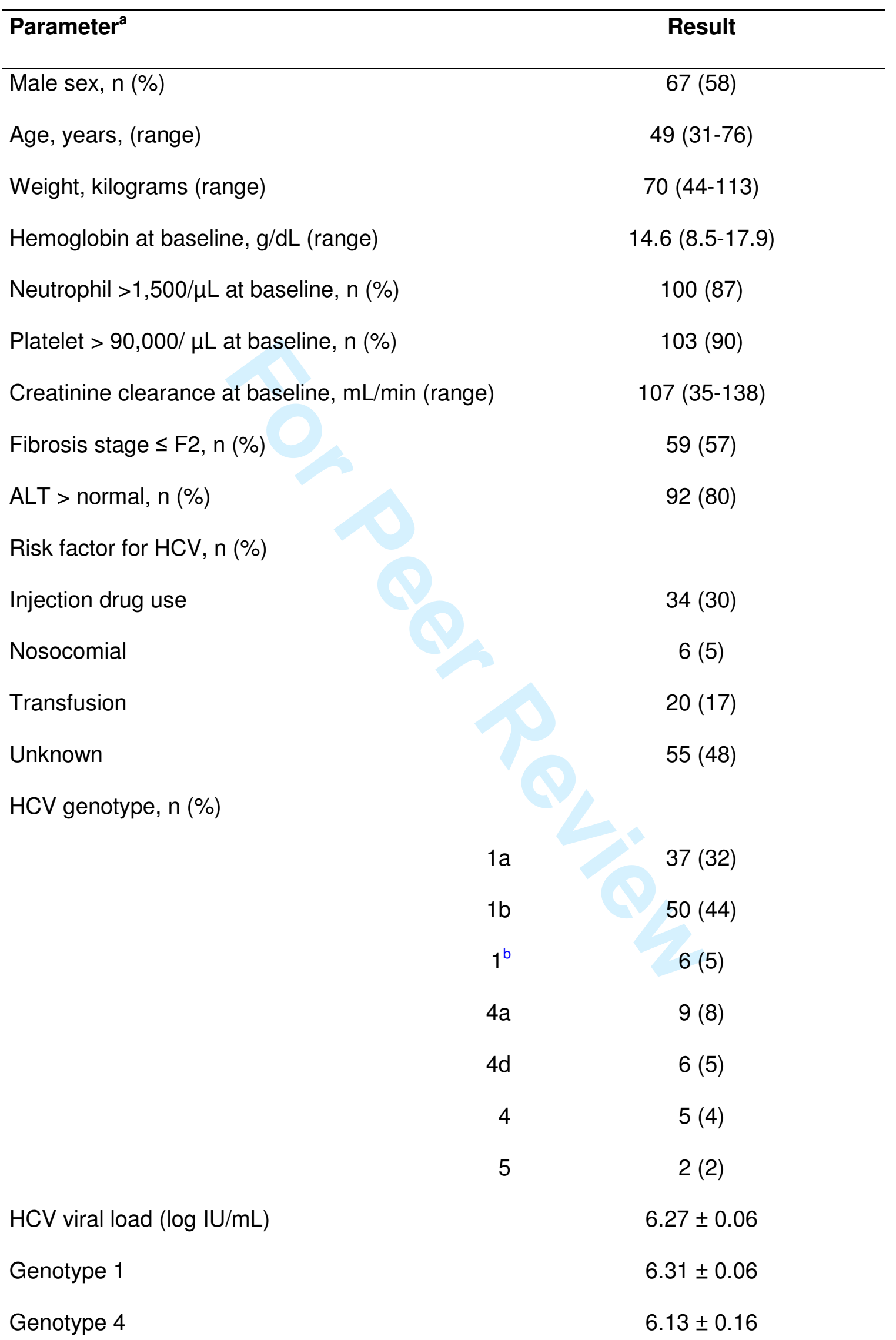


$>800,000 \mathrm{IU} / \mathrm{mL}, \mathrm{n}(\%)$

HIV positive , n (\%)

Patient treatment status at inclusion, n (\%)

Naïve

Non-responder

$48(42)$

Unknown

Ribavirin dose, n (\%)

$800 \mathrm{mg}$

$1000 \mathrm{mg}$

$1200 \mathrm{mg}$

Ribavirin weight-adjusted dose, mg/kg (range)

$14.3(9.2-25)$

Concomitant antiretroviral therapy, $\mathrm{n}$

21 (18)

1 aLT, alanine aminotranferase

$2{ }^{b}$ HCV genotype 1: $1 d(n=1), 1 i(n=1), 1$ with undetermined subtype $(n=4)$ 
1 Table II: Factors associated with an early virological response. Parameters with a p value

$2<0.10$ by one-variable analysis are in bold.

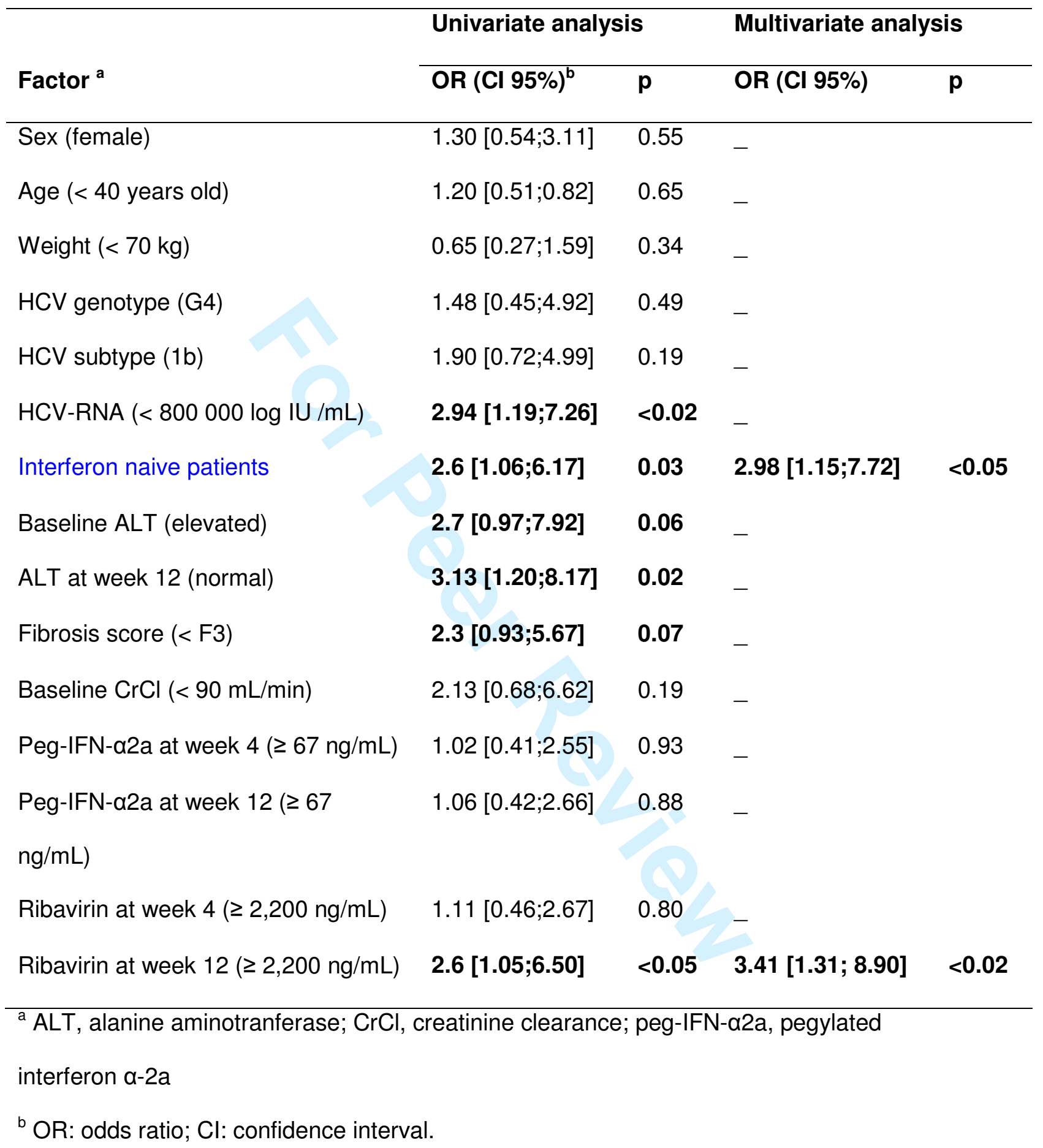


1 Table III: Factors associated with sustained virological response. Parameters with a $p$ value

$2<0.10$ by univariate analysis are in bold.

\section{Univariate analysis Multivariate analysis}

\begin{tabular}{|c|c|c|c|c|}
\hline Factor $^{a}$ & OR (Cl 95\%) ${ }^{b}$ & $\mathbf{p}$ & OR (Cl 95\%) & $\mathbf{p}$ \\
\hline Sex (female) & $1.19[0.54 ; 2.66]$ & 0.66 & - & \\
\hline Age $(<40$ years old $)$ & $0.82[0.37 ; 1.81]$ & 0.59 & - & \\
\hline Weight $(<70$ kg) & $1.10[0.48 ; 2.50]$ & 0.79 & - & \\
\hline HCV genotype (G4) & $1.05[0.37 ; 2.99]$ & 0.89 & - & \\
\hline HCV subtype (1b) & $3.15[1.14 ; 8.70]$ & $<0.05$ & $6.82[1.7 ; 26.8]$ & $<0.01$ \\
\hline HCV-RNA (< $800000 \log \mathrm{IU} / \mathrm{mL})$ & $1.44[0.65 ; 3.19]$ & 0.37 & - & \\
\hline Previous anti-HCV therapy (no) & $1.56[0.69 ; 3.52]$ & 0.28 & - & \\
\hline Baseline ALT (elevated) & $1.41[0.45 ; 4.40]$ & 0.52 & - & \\
\hline ALT at week 12 (normal) & $2.79[1.14 ; 6.86]$ & $<0.05$ & - & \\
\hline Fibrosis score (< F3) & $1.15[0.50 ; 2.65]$ & 0.72 & - & \\
\hline Baseline $\mathrm{CrCl}(<90 \mathrm{~mL} / \mathrm{min})$ & $1.17[0.39 ; 3.55]$ & 0.75 & - & \\
\hline HCV RNA at week $4(<15 \mathrm{IU} / \mathrm{mL})$ & $3.2[0.96 ; 10.66]$ & 0.05 & - & \\
\hline HCV RNA at week $12(<15 \mathrm{IU} / \mathrm{mL})$ & $13[4.86 ; 34.95]$ & $<0.001$ & $25[6.4 ; 97.6]$ & $<0.001$ \\
\hline HCV RNA drop at week 12 ( $\geq 2 \log )$ & $30[3.9 ; 234.6]$ & $<0.001$ & - & \\
\hline Peg-IFN- $\alpha 2 a$ at week 4 ( $\geq 67 \mathrm{ng} / \mathrm{mL})$ & $1.07[0.45 ; 2.5]$ & 0.85 & - & \\
\hline Peg-IFN- $\alpha 2 a$ at week $12(\geq 67$ & $1.33[0.55 ; 3.25]$ & 0.50 & - & \\
\hline
\end{tabular}

Ribavirin at week $4(\geq 2,200 \mathrm{ng} / \mathrm{mL}) \quad 0.78[0.35 ; 1.78] \quad 0.54$

Ribavirin at week $12(\geq 2,200 \mathrm{ng} / \mathrm{mL}) \quad 2.16[0.93 ; 5.05] \quad 0.07$

$3{ }^{a} \mathrm{ALT}$, alanine aminotranferase; $\mathrm{CrCl}$, creatinine clearance; peglFN- $\alpha 2 \mathrm{a}$, pegylated interferon

$4 \quad \alpha-2 a$

$5 \quad$ b OR: odds ratio; $\mathrm{Cl}$ : confidence interval. 
Fig.1

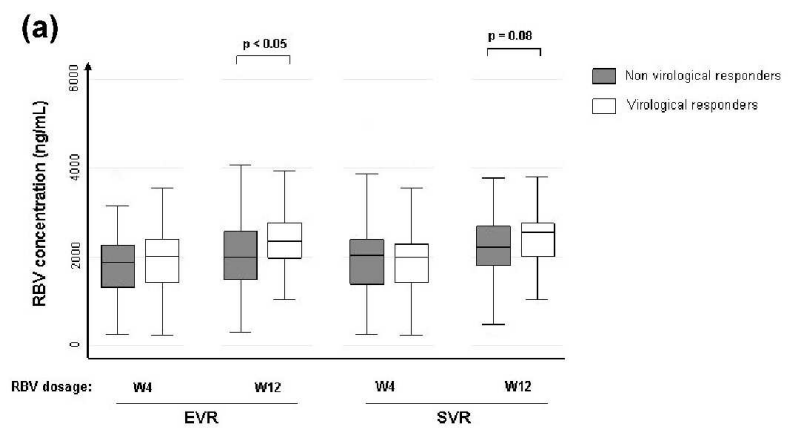

(b)

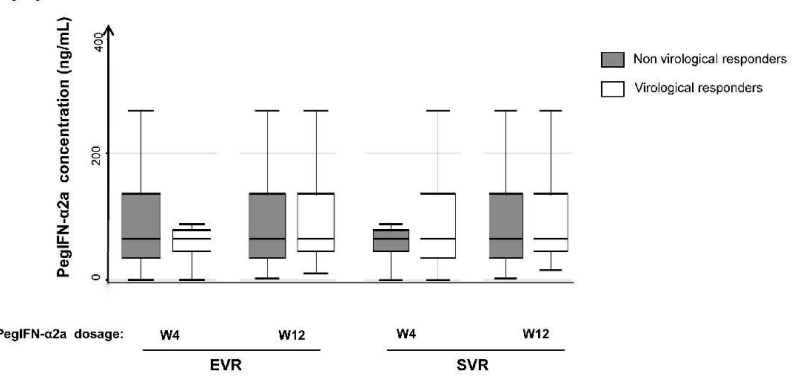

(b)

$186 \times 356 \mathrm{~mm}(300 \times 300 \mathrm{DPI})$

John Wiley \& Sons 
Fig. 2

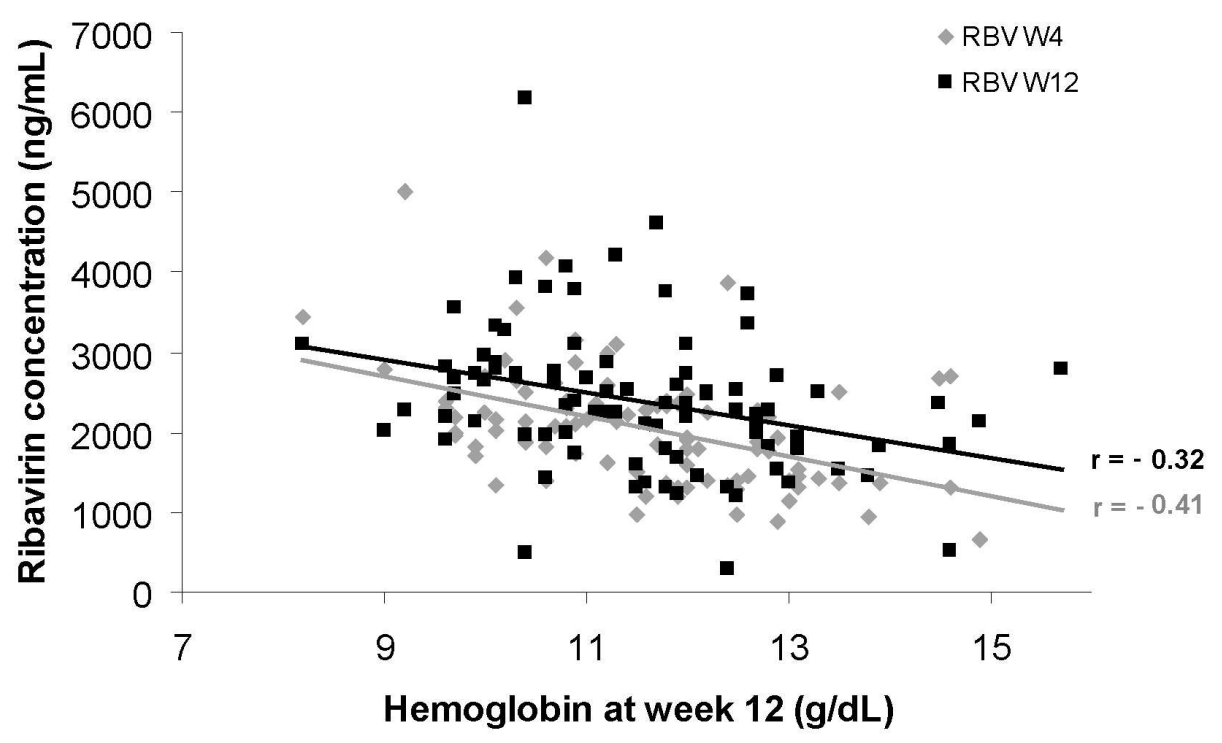

$150 \times 99 m m(300 \times 300$ DPI $)$ 
1 INFLUENCE OF HCV GENOTYPE 1 SUBTYPES ON THE VIRUS RESPONSE TO PEG

\section{INTERFERON ALPHA-2a PLUS RIBAVIRIN THERAPY}

3

4 Running head: HCV genotype 1 subtypes and the response to anti-HCV therapy 5

6 F. Nicot ${ }^{1}$, L. Alric ${ }^{2,3,4}$, K. Barange ${ }^{5}$, S. Métivier ${ }^{5}$, J.M. Dramard ${ }^{6}$, J.M. Combis ${ }^{7}$, B. Castan ${ }^{8}$, J.J

7 Meurisse $^{9}$, J.L. Payen ${ }^{10}$, D.Garipuy ${ }^{11}$, H.Desmorat ${ }^{12}$, J.M Peron $^{5}$, S. Thebault ${ }^{2}$, T.Morin $^{13}$, C.

8 Renou $^{14}$, P. Barel ${ }^{15}$, B. Guerin ${ }^{16}$, Y. Imbert ${ }^{17}$, S. Sire ${ }^{18}$, K. Sauné ${ }^{1,4,19}$, E. Chatelut ${ }^{4,20}$, J.

9 Izopet $^{1,4,19^{*}}$

11 From the

$12{ }^{1}$ CHU Toulouse, IFB Purpan, Laboratoire de Virologie, Toulouse, F-31300, France;

$13{ }^{2}$ Internal Medicine, Purpan, Toulouse University Hospital, France;

$14{ }^{3}$ EA2405 UMR3 MD-UM-UPS, Université Paul Sabatier Toulouse III, France

$15{ }^{4}$ Université Toulouse III Paul-Sabatier, Toulouse, F-31062 France ;

$16{ }^{5}$ Gastroenterology, Purpan, Toulouse University Hospital, France;

$17{ }^{6}$ Gastroenterology, Val d'Ariège Hospital, Pamiers, France;

$18{ }^{7}$ Gastroenterology, Ambroise Paré Clinic, Toulouse, France ;

$19{ }^{8}$ General Medicine, Auch Hospital, Auch, France;

$20{ }^{9}$ Gastroenterology, Lourdes Hospital, Lourdes, France;

$21{ }^{10}$ Internal Medicine, Montauban Hospital, Montauban, France;

$22{ }^{11}$ Ducuing Hospital, Toulouse, France;

$23{ }^{12}$ Polyclinique du Parc, Toulouse, France;

$24{ }^{13}$ Gastroenterology, Bigorre Hospital, Tarbes, France;

$25{ }^{14}$ Hyères Hospital, Hyères, France ;

$26{ }^{15}$ Albi Hospital, Albi, France ;

$27{ }^{16}$ Internal Medicine, Rodez Hospital, Rodez, France ;

$28{ }^{17}$ Internal Medicine, Agen Hospital, Agen, France; 
1

2

3

4

5

6

7

8

9

10

12

13

14

15

16

17

18

19

20

21

22

23

24

25

26

27

28

29

30

31

32

33

34

35

36

37

38

39

40

41

42

43

44

45

46

47

48

49

50

51

52

53

54

55

56

57

58

59

60

$1{ }^{18}$ Gastroenterology, Cahors Hospital, Cahors, France;

$2{ }^{19}$ INSERM, U.563, Toulouse, F-31300 France;

$3{ }^{20}$ EA3035, Institut Claudius-Regaud, F-31052 Toulouse, France;

4

5 * Jacques Izopet

6 Laboratoire de virologie - IFB, CHU Toulouse Purpan

7330 , avenue de Grande-Bretagne

831059 Toulouse cedex

9 France

10 Tel: (33) 569690424

11 Fax: (33) 569690425

12 E-Mail: izopet.j@chu-toulouse.

13

14

15 Abstract word count: 236

16 Text word count: 2,623 


\section{ABSTRACT}

3 New factors that influence the viral response in HCV non-genotype 2/3 patients must be 4 identified in order to optimize anti-HCV treatment. This multicenter prospective study 5 evaluates the influence of HCV variability and pharmacological parameters on the virological 6 response of these patients to pegylated interferon $\alpha 2 a$ (peg-IFN- $\alpha 2 a: 180 \mu \mathrm{g} /$ week) and 7 ribavirin (800-1200 mg/day) for 48 weeks. HCV subtypes were identified by sequencing the 8 NS5B region. Serum ribavirin and peg-IFN- $\alpha 2 a$ concentrations were measured at weeks 4 9 and 12. The 115 patients (67 men; median age=49, range [31-76]) included 64 who had 10 never been treated and 27 co-infected with HIV. The mean baseline HCV RNA was $6.30 \pm$ $110.06 \log \mathrm{IU} / \mathrm{mL}$ and the HCV genotypes were: G1 $(\mathrm{n}=93)$ with $1 \mathrm{a}(\mathrm{n}=37)$ and $1 \mathrm{~b}(\mathrm{n}=50), \mathrm{G} 4$ $12(n=20)$ and G5 ( $n=2)$. Most patients $(79 / 108 ; 73 \%)$ had an early virological response. 13 Independent predictors of an early virological response were interferon naive patients $14(\mathrm{OR}=2.98[1.15 ; 7.72])$ and ribavirin of $>2,200 \mathrm{ng} / \mathrm{mL}$ at week $12(\mathrm{OR}=3.41[1.31 ; 8.90])$. 15 Forty of 104 patients (38\%) had a sustained virological response. The only independent 16 predictors of a sustained virological response were subtype $1 \mathrm{~b}(\mathrm{OR}=6.82[1.7 ; 26.8])$, and $17 \mathrm{HCV}$ RNA $<15 \mathrm{IU} / \mathrm{mL}$ at week $12(\mathrm{OR}=25[6.4 ; 97.6])$. Thus a serum ribavirin concentration 18 of $>2,200 \mathrm{ng} / \mathrm{mL}$ was associated with an early virological response and patients infected with 19 HCV subtype $1 \mathrm{~b}$ had a better chance of a sustained virological response than did those 20 infected with subtype $1 \mathrm{a}$.

22 KEY WORDS: Hepatitis C, HCV subtype, ribavirin concentration 


\section{INTRODUCTION}

2

The hepatitis $\mathrm{C}$ virus $(\mathrm{HCV})$ is very variable, with 6 genotypes and more than 70 subtypes [Simmonds et al., 2005; Simmonds et al., 1993]. Various factors (viral, host and pharmacological one) can influence the overall rate of sustained virological response to ribavirin (RBV) and pegylated interferon alpha (peglFNa) treatment that is only $50-60 \%$ [Conjeevaram et al., 2006; Conjeevaram et al., 2007; Everson et al., 2006; Fried, 2002; Ge et al., 2009; Manns et al., 2001; Zeuzem, 2004].

Genotype is considered to be the most important factor predicting the virological response. Patients infected with HCV genotype 1 or 4 are considered to be difficult-to-treat, as only $40 \%$ achieve a sustained virological response [Fried et al., 2002; Hadziyannis et al., 2004; Manns et al., 2001; Zeuzem, 2004]. Little is known at present about the influence of HCV subtypes on the virological response. Most studies, including the pivotal studies, have determined the genotype by analysing the 5'UTR region [Fried et al., 2002; Manns et al., 2001]. This makes it difficult to discriminate accurately between HCV subtypes [Chen and Weck, 2002; Halfon et al., 2001]. The NS5B region is considered to be the most appropriate region of the HCV genome for accurately determining the HCV subtype [Cantaloube et al., 2006; Nicot et al., 2005; Sandres-Saune et al., 2003] and for studying the virological response of different subtypes.

There are few published data on the influence of pharmacological parameters on the virological response and many of them are based on analyses of small numbers of patients. Most studies have shown that a low ribavirin concentration is associated with a poor virological response [Aguilar Marucco et al., 2008; Larrat et al., 2003; Lindahl et al., 2005; Maynard et al., 2008; Nicot et al., 2008; Rendon et al., 2005] in patients infected with HCV genotypes 1 or 4 , but there are some conflicting data [Crespo et al., 2007; Dahari et al., 2007; Lopez-Cortes et al., 2008]. Likewise, there are few data on the peg-IFN- $\alpha$ concentration and its influence on the virological response [Lopez-Cortes et al., 2008; Nicot et al., 2008; Talal et al., 2006]. 
1 This prospective study on difficult-to-treat patients infected with HCV genotypes 1, 4 2 or 5 investigates the intrinsic sensitivity of HCV subtypes to peg-IFN- $\alpha 2 a$ and ribavirin and 3 the influence of pharmacological parameters on the virological response (early virological 4 response and sustained virological response). 5 


\section{PATIENTS AND METHODS}

2

\section{Patients}

4

5

A total of 115 patients infected chronically with HCV attending the Toulouse University Hospital and 13 General Hospitals in the Midi-Pyrénées area were enrolled in this prospective study between June 2005 and December 2007. The inclusion criteria were: age $>18$ years, HCV genotype 1, 4, 5 or 6 and treatment initiation with peg-IFN- $\alpha 2 a$ and ribavirin. Patients coinfected with HCV and HIV were also included.

This study was approved by the Toulouse University Hospital Ethic Committee. All the patients provided written informed consent before participating in the study.

\section{Treatment and monitoring}

Patients were treated with $180 \mu \mathrm{g}$ peg-IFN- $\alpha 2 a$ (Pegasys ${ }^{\circledR}$, Roche), given subcutaneously once a week, in combination with ribavirin (Copegus ${ }^{\circledR}$, Roche) adjusted for body weight, for 48 weeks. Treatment was stopped if the plasma HCV RNA concentration at week 12 had decreased by $<2 \log \mathrm{IU} / \mathrm{mL}$. All patients were seen $4,8,12,24,48$ weeks after the initial interview and 4 and 24 weeks after treatment withdrawal. Serum samples were collected at each time, centrifuged within 2 hours and stored at $-80^{\circ} \mathrm{C}$. Patients with an undetectable HCV RNA concentration at week 4 were considered to be rapid virological responders. Patients with a $>2$ log decrease in plasma HCV RNA at week 12 were considered to be early virological responders. Patients with undetectable HCV RNA 24 weeks after treatment withdrawal were considered to be sustained virological responders. 


\section{$1 \quad$ Virological parameters}

3 Plasma HCV-RNA was measured at baseline, 4, 12, 48, 52 and 72 weeks by the real-time

4 RT-PCR COBAS ${ }^{\mathrm{TM}}$ Ampliprep/COBAS ${ }^{\mathrm{TM}}$ Taqman HCV test (CAP/CTM; Roche Diagnostics, 5 Meylan, France), according to the manufacturer's instructions. Plasma HIV-RNA was 6 measured every 3 months by the real-time RT-PCR COBAS ${ }^{\text {TM }}$ Ampliprep/COBAS $^{\text {TM }}$ Taqman 7 HIV test (CAP/CTM; Roche Diagnostics, Meylan, France) according to the manufacturer's 8 instructions. HCV genotypes and subtypes were determined by phylogenetic analysis of the

9 NS5b region of the HCV genome as described previously [Sandres-Saune et al., 2003].

\section{Determination of serum peg-IFN- $\alpha 2 a$ concentrations}

The residual peg-IFN- $\alpha 2 a$ concentrations in serum samples taken at 4 and 12 weeks were measured with a bioassay [Boulestin et al., 2004]. The assay evaluates the capacity of the peg-IFN- $\alpha 2 a$ in serum samples to reduce the cytopathic effect of the vesicular stomatitis virus on MDBK cells in culture. The reference solutions contained 2.8 to $180 \mathrm{ng} / \mathrm{mL}$ of peg17 IFN- $\alpha 2 a$ (Roche, France).

\section{Determination of serum ribavirin concentrations}

21 Residual serum ribavirin concentrations ( $\left.C_{\text {residual }}\right)$ were determined 4 and 12 weeks after 22 treatment initiation by high-performance liquid chromatography (HPLC) [Kamar et al., 2004; 23 Svensson et al., 2000]. Briefly, ribavirin was extracted with phenyl boronic acid Bond Elute $24100 \mathrm{mg} / \mathrm{PK}$ cartridges (Varian SA) and analysed on a Bischoff Nucléosil ${ }^{\mathrm{R}} \mathrm{C} 187 \mu \mathrm{m}$ column 25 with ultraviolet detection at $215 \mathrm{~nm}$. The method was linear from 250 to $6,000 \mathrm{ng} / \mathrm{mL}$. The 26 average within-run and between-run precision was better than $15 \%$ for high and medium 27 concentration control samples, and better than $20 \%$ for low concentrations. 


\section{1}

2

3

4

5

6

7

8

\section{Statistical analysis}

2

3 Statistical analyses were performed with STATA 8.0 software (Stata corporation, Grand

4 Forks, ND). Continuous variables were evaluated with the Mann-Whitney or Wilcoxon tests.

5 Categorical variables were tested by the Chi-squared test. Receiving operating

6 characteristics (ROC) curves were constructed with the ribavirin concentrations at week 12 to

7 determine the cut-off point that best discriminated between virological responders and non-

8 responders at week 12 . A p value of less than 0.05 was considered to be significant.

9 Predictors of early virological response and sustained virological response were evaluated by

10 univariate and multivariate analyses. Variables with a $p$ value of 0.10 or less after univariate

11 analysis were entered into a multivariate, backward, stepwise logistic regression analysis to

12 identify significant variables independently associated with the virological response.

13 


\section{RESULTS}

\section{Patient characteristics, treatment response and tolerance}

4

The baseline patient characteristics are summarized in Table I. Most were infected with HCV genotype $1(n=93,81 \%)$ and HCV genotype $4(n=20,17 \%)$ and 27 of them $(23 \%)$ were coinfected with HIV.

Only $13 / 108$ patients (12\%) achieved a rapid virological response at week 4 , while 79/108 patients (73\%) achieved an early virological response at week 12, including 53 (49\%) who had undetectable HCV RNA. At the end of follow-up, 40/104 patients (38\%) had a sustained virological response, as did $35 / 88$ patients (39.8\%) with HCV-1 and 7/19 (36.8\%) with HCV-4 $(p=N S)$. One of the patients infected with HCV-5 discontinued treatment before week 12 and the other achieved a sustained virological response. Also 7/31 (22.6\%) patients infected with HCV-1a achieved a sustained virological response, as did 23/48 (48\%) of those infected with HCV-1b $(p<0.02)$, and in 2/6 (33\%) of those infected with HCV-1 other than 1a or 1 b. A sustained virological response was observed in $8 / 25$ patients $(32 \%)$ coinfected with HIV. This percentage was not significantly different from that of patients infected with HCV alone $(40.5 \%)(p=N S)$. A sustained virological response was observed in $1 / 8(12.5 \%)$ patients infected with HCV genotype 1a who were coinfected with HIV and in 3/4 (75\%) patients infected with HCV genotype $1 \mathrm{~b}$ coinfected with HIV $(p=0.03)$.

Seven patients discontinued treatment before week 12 due to intolerance to treatment (severe anemia or neutropenia, $n=6)$, or death unrelated to anti-HCV treatment $(n=1)$. Four patients with an undetectable HCV RNA viral load at week 48 were lost to follow-up after week 48. Adverse haematological events led to the initial treatment of 32 patients $(29.6 \%)$ being modified. Fourteen patients were given erythropoietin and 7 were given neutrophil growth factors. 


\section{1}

\section{Serum concentrations of ribavirin}

2

The mean serum ribavirin $C_{\text {residual }}$ were $1,991 \pm 76 \mathrm{ng} / \mathrm{mL}$ at week 4 and 2,355 \pm 88 $\mathrm{ng} / \mathrm{mL}$ at week 12. Figure 1a shows the serum ribavirin concentrations at weeks 4 and 12 in terms of the early virological response and sustained virological response. The serum ribavirin $\mathrm{C}_{\text {residual }}$ concentrations at week 12 were significantly higher in patients with an early virological response $(2,424 \pm 94 \mathrm{ng} / \mathrm{mL})$ than in those with no early virological response $(2,162 \pm 205 \mathrm{ng} / \mathrm{mL})(\mathrm{p}<0.05)$. ROC curve analysis showed that the best cut-off value for discriminating between patients with an early virological response and those with no early virological response was $2,200 \mathrm{ng} / \mathrm{mL}$ (area under the curve $=0.66 ; 95 \% \mathrm{Cl}, 0.53-0.79$; sensitivity: $62 \%$, specificity: $69 \%$ ). The serum ribavirin concentration at week 12 tended to be higher in patients with a sustained virological response $(2,538 \pm 121 \mathrm{ng} / \mathrm{mL})$ than in those with no sustained virological response $(2,296 \pm 123 \mathrm{ng} / \mathrm{mL})(\mathrm{p}=0.08)$.

The ribavirin treatment led to a drop in circulating hemoglobin $(\mathrm{Hb})$ of $-3.1 \mathrm{mg} / \mathrm{dL}(-$ $6.30 ; 3.13)$ between baseline and week 12 ; it reached a median value of $11.7 \mathrm{~g} / \mathrm{dL}(8.2 ; 15.7)$ at week 12. The serum ribavirin concentrations at week $4(r=-0.41, p<0.001)$ and week 12 $(r=-0.32, p<0.002)$ were inversely correlated with the $\mathrm{Hb}$ concentration at week 12 (Figure 2).

\section{Serum concentrations of peg-IFN- $\alpha 2 a$}

The mean serum peg-IFN- $\alpha 2 a C_{\text {residual }}$ was $92 \pm 9 \mathrm{ng} / \mathrm{mL}$ at week 4 , and $100 \pm 11$ $\mathrm{ng} / \mathrm{mL}$ at week 12. No relationship was found between the serum peg-IFN- $22 \mathrm{a}$ concentrations at weeks 4 and 12 and the early or sustained virological responses (Figure 1b). 


\section{Factors predicting the virological response}

2

3

One-variable analysis found that 6 factors were associated with an early virological

4 response (Table II). The factors that remained independently associated with the early

5 virological response in the logistic regression analysis were: interferon naive patients, and a

6 serum ribavirin $\mathrm{C}_{\text {residual }}>2,200 \mathrm{ng} / \mathrm{mL}$ at week 12 (Table II). As all the patients with a rapid

7 virological response $(n=13)$ also had an early virological response, this factor was not

$8 \quad$ included in the statistical analysis.

9 One-variable analysis revealed 6 factors that were associated with a sustained 10 virological response (Table III). The factors that remained independently associated with a 11 sustained virological response in the logistic regression model were subtype $1 \mathrm{~b}$ and an 12 undetectable HCV RNA concentration at week 12 (Table III). 


\section{DISCUSSION}

2

This is the first prospective study on HCV genotypes 1 or 4 that evaluates the influence of the virus subtype and the serum concentrations of peg-IFNa-2a and ribavirin on the virological response. A ribavirin concentration of $>2,200 \mathrm{ng} / \mathrm{mL}$ was identified as a factor associated with an early virological response. HCV subtype $1 \mathrm{~b}$ was identified as a predictive factor of a sustained virological response. Unlike clinical trials, this cohort study included patients that were representative of the population followed by the clinicians.

Several studies have reported a correlation between an early virological response and/or a sustained virological response and the ribavirin $\mathrm{C}_{\text {residual }}$ [Jen et al., 2000; Larrat et al., 2003; Maynard et al., 2008; Rendon et al., 2005; Tsubota et al., 2003]. A plasma ribavirin concentration threshold of 2,000 to $3,000 \mathrm{ng} / \mathrm{mL}$ at weeks 4 or 12 was proposed to maximize the rate of response [Larrat et al., 2003; Lindahl et al., 2005; Maynard et al., 2008; Nicot et al., 2008]. The patients in the present study with a serum ribavirin concentration of $>2,200$ $\mathrm{ng} / \mathrm{mL}$ had more chance of achieving an early virological response. Although no association was found between the serum ribavirin concentration at week 12 and the sustained virological response (probably due to a lack of statistical power), this concentration tended to be higher in responders than in non-responders, as observed in a previous study on patients infected with HCV genotype 1 [Breilh et al., 2009]. The Hb concentration at week 12 was inversely correlated with the ribavirin concentrations, which is consistent with other studies [Arase et al., 2005; Jen et al., 2000; Loustaud-Ratti et al., 2008; Maeda et al., 2004]. Cut-off values of 2,300 or $2,800 \mathrm{ng} / \mathrm{mL}$ were proposed for predicting haematological toxicity in patients infected with both HIV and HCV [Aguilar Marucco et al., 2008; Rendon et al., 2005]. The optimal times for measuring the ribavirin concentration and the clinical ribavirin threshold in order to maximize the anti-HCV response and minimize the haematological effects have yet to be determined.

The data in the present study indicate that the serum peg-IFN- $\alpha 2 a$ concentrations were not associated with an early virological response or a sustained virological response. 
1 This is in keeping with the findings for patients infected with HCV and HIV [Nicot et al., 2008;

2 Talal et al., 2006]. Another study on HIV-positive patients infected with HCV genotype 1 or 4

3 found that patients with a high plasma peg-IFN- $\alpha 2$ a concentration throughout treatment were

43 to 4 times more likely to achieve a sustained virological response than those with a low

5 plasma peg-IFN- $\alpha 2 a$ concentration [Lopez-Cortes et al., 2008]. These discordant results

6 between studies can be explained at least in part by differences in time of sampling. Its

7 impact on the virological response remains to determine.

The HCV genotype is a major determinant of the response to treatment for chronic

9 hepatitis C. Several clinical trials have found that patients infected with genotypes 1 or 4 are

10 less likely to achieve a sustained virological response than others [Fried et al., 2002;

11 Legrand-Abravanel et al., 2005; Manns et al., 2001; Martin-Carbonero et al., 2004; Roulot et

12 al., 2007]. Many of them were performed with the first version of the INNO-LIPA HCV assay

13 that misclassifies a significant percentage of genotype 1a isolates as genotype $1 \mathrm{~b}$ [Chen and

14 Weck, 2002]. HCV subtypes in the present study were identified by sequencing the NS5b

15 region, which accurately discriminates between subtypes [Cantaloube et al., 2006; Nicot et 16 al., 2005; Sandres-Saune et al., 2003; Thomas et al., 2007]. Those patients infected with 17 subtype 1a had less chance of clearing their HCV infection than did patients infected with 18 subtype 1 b, which agrees well with a previous study [Legrand-Abravanel et al., 2009]. The 19 subtype did not influence the early virological response: the viral responses at week 12 in 20 patients infected with subtype $1 \mathrm{a}(62.5 \%)$ and $1 \mathrm{~b}(76 \%)$ were similar. Recent data suggest 21 that the treatment duration of patients infected with HCV genotype 1 could be adapted 22 according to the HCV RNA concentrations. Evidence from several clinical trials supports the 23 case for extending the treatment time for patients with HCV genotype 1 and a slow virological 24 response to 72 weeks [Berg et al., 2006; Pearlman et al., 2007]. Knowing the HCV subtype 25 of patients infected with genotype 1 could also help to optimize anti-HCV treatment. Several 26 new drugs that target the virus, including protease and polymerase inhibitors, have also 27 focused on HCV genotype 1 infections. Studies investigating telaprevir in combination with 28 peg-IFN- $\alpha$ and ribavirin found that a virological breakthrough due to resistance emerged 
1 more frequently in patients harboring subtype 1a [McHutchison et al., 2009; Sarrazin and

2 Zeuzem, 2010].

Recent independent genome-wide association studies have identified single

4 nucleotide polymorphisms near the IL28B region as being associated with the response to

5 peg-IFN- $\alpha$ and ribavirin treatment [Ge et al., 2009; Suppiah et al., 2009; Tanaka et al., 2009].

6 The association was observed in individuals infected with HCV alone and in those coinfected

7 with HCV and HIV. The association was strongest in patients with HCV genotypes 1 or 4

8 [Rauch et al., 2010]. These combined virological, pharmacological and host factors will be

9 analysed in future studies.

10 To conclude, a high ribavirin concentration is associated with a higher rate of early 11 virological response. An important finding is that the HCV subtype 1a responds less well to 12 treatment than does HCV subtype 1b. The HCV subtype could therefore be relevant for 13 managing the anti-HCV therapy of individual patients and for assessing the efficacy of new 14 combined treatments with drugs that target specifically the virus. 


\section{ACKNOWLEDGEMENTS}

2 We thank Thierry Lafont for technical assistance. The English text was edited by Dr Owen

3 Parkes. This work was supported by Roche (France). We are grateful to Natalia Kharlov for 4 her help.

5

\section{CONFLICT OF INTEREST}

7 None. 


\section{REFERENCES}

2 Aguilar Marucco D, Gonzalez de Requena D, Bonora S, Tettoni C, Bonasso M, De Blasi T, D'Avolio A, Sciandra M, Siccardi M, Baietto L, Trentini L, Sinicco A, Cariti G, Di Perri G. 2008. The use of residual ribavirin concentration to predict sustained virological response and haematological toxicity in $\mathrm{HIV} / \mathrm{HCV}-\mathrm{co}-\mathrm{infected}$ patients treated with ribavirin and pegylated interferon. J Antimicrob Chemother 61(4):919924.

Arase Y, Ikeda K, Tsubota A, Suzuki F, Suzuki Y, Saitoh S, Kobayashi M, Akuta N, Someya T, Hosaka T, Sezaki H, Kumada H. 2005. Significance of serum ribavirin concentration in combination therapy of interferon and ribavirin for chronic hepatitis C. Intervirology 48(2-3):138-144.

Berg T, von Wagner M, Nasser S, Sarrazin C, Heintges T, Gerlach T, Buggisch P, Goeser T, Rasenack J, Pape GR, Schmidt WE, Kallinowski B, Klinker H, Spengler U, Martus P, Alshuth U, Zeuzem S. 2006. Extended treatment duration for hepatitis C virus type 1: comparing 48 versus 72 weeks of peginterferon-alfa-2a plus ribavirin. Gastroenterology 130(4):1086-1097.

Boulestin A, Kamar N, Legrand-Abravanel F, Sandres-Saune K, Alric L, Vinel JP, Rostaing L, Izopet J. 2004. Convenient biological assay for polyethylene glycol-interferons in patients with hepatitis C. Antimicrob Agents Chemother 48(9):3610-3612.

Breilh D, Foucher J, Castera L, Trimoulet P, Djabarouti S, Merrouche W, Couzigou P, Saux MC, de Ledinghen V. 2009. Impact of ribavirin plasma level on sustained virological response in patients treated with pegylated interferon and ribavirin for chronic hepatitis C. Alimentary pharmacology \& therapeutics 30(5):487-494. 
1 Cantaloube JF, Laperche S, Gallian P, Bouchardeau F, de Lamballerie X, de Micco P. 2006. Analysis of the 5' noncoding region versus the NS5b region in genotyping hepatitis C virus isolates from blood donors in France. J Clin Microbiol 44(6):2051-2056.

Chen Z, Weck KE. 2002. Hepatitis C virus genotyping: interrogation of the 5' untranslated region cannot accurately distinguish genotypes $1 \mathrm{a}$ and $1 \mathrm{~b}$. J Clin Microbiol 40(9):3127-3134.

Conjeevaram HS, Fried MW, Jeffers LJ, Terrault NA, Wiley-Lucas TE, Afdhal N, Brown RS, Belle SH, Hoofnagle JH, Kleiner DE, Howell CD. 2006. Peginterferon and ribavirin treatment in African American and Caucasian American patients with hepatitis C genotype 1. Gastroenterology 131(2):470-477.

Conjeevaram HS, Kleiner DE, Everhart JE, Hoofnagle JH, Zacks S, Afdhal NH, Wahed AS. 2007. Race, insulin resistance and hepatic steatosis in chronic hepatitis C. Hepatology 45(1):80-87.

Crespo M, Pou L, Esteban JI, Falco V, Ribera E, Lopez R, Sauleda S, Curran A, Villar del Saz S, Feijoo M, Ocana I, Pahissa A. 2007. Early monitoring of ribavirin serum concentration is not useful to optimize hepatitis $\mathrm{C}$ virus treatment in HIV-coinfected patients. Antivir Ther 12(8):1217-1223.

Dahari H, Markatou M, Zeremski M, Haller I, Ribeiro RM, Licholai T, Perelson AS, Talal AH. 2007. Early ribavirin pharmacokinetics, HCV RNA and alanine aminotransferase kinetics in HIV/HCV co-infected patients during treatment with pegylated interferon and ribavirin. J Hepatol 47(1):23-30.

Everson GT, Hoefs JC, Seeff LB, Bonkovsky HL, Naishadham D, Shiffman ML, Kahn JA, Lok AS, Di Bisceglie AM, Lee WM, Dienstag JL, Ghany MG, Morishima C. 2006. Impact of disease severity on outcome of antiviral therapy for chronic hepatitis $\mathrm{C}$ : Lessons from the HALT-C trial. Hepatology 44(6):1675-1684. 
1 Fried MW. 2002. Side effects of therapy of hepatitis C and their management. Hepatology

2

3 36(5 Suppl 1):S237-244.

Fried MW, Shiffman ML, Reddy KR, Smith C, Marinos G, Goncales FL, Jr., Haussinger D, Diago M, Carosi G, Dhumeaux D, Craxi A, Lin A, Hoffman J, Yu J. 2002. Peginterferon alfa-2a plus ribavirin for chronic hepatitis $\mathrm{C}$ virus infection. N Engl $\mathbf{J}$ Med 347(13):975-982.

Ge D, Fellay J, Thompson AJ, Simon JS, Shianna KV, Urban TJ, Heinzen EL, Qiu P, Bertelsen AH, Muir AJ, Sulkowski M, McHutchison JG, Goldstein DB. 2009. Genetic variation in IL28B predicts hepatitis C treatment-induced viral clearance. Nature 461(7262):399-401.

Hadziyannis SJ, Sette H, Jr., Morgan TR, Balan V, Diago M, Marcellin P, Ramadori G, Bodenheimer H, Jr., Bernstein D, Rizzetto M, Zeuzem S, Pockros PJ, Lin A, Ackrill AM. 2004. Peginterferon-alpha2a and ribavirin combination therapy in chronic hepatitis C: a randomized study of treatment duration and ribavirin dose. Ann Intern Med 140(5):346-355.

Halfon P, Trimoulet P, Bourliere M, Khiri H, de Ledinghen V, Couzigou P, Feryn JM, Alcaraz P, Renou C, Fleury HJ, Ouzan D. 2001. Hepatitis C virus genotyping based on 5' noncoding sequence analysis (Trugene). J Clin Microbiol 39(5):1771-1773.

Jen JF, Glue P, Gupta S, Zambas D, Hajian G. 2000. Population pharmacokinetic and pharmacodynamic analysis of ribavirin in patients with chronic hepatitis C. Ther Drug Monit 22(5):555-565.

Kamar N, Chatelut E, Manolis E, Lafont T, Izopet J, Rostaing L. 2004. Ribavirin pharmacokinetics in renal and liver transplant patients: evidence that it depends on renal function. Am J Kidney Dis 43(1):140-146. 
1 Larrat S, Stanke-Labesque F, Plages A, Zarski JP, Bessard G, Souvignet C. 2003. Ribavirin

2

3

4 5 quantification in combination treatment of chronic hepatitis C. Antimicrob Agents Chemother 47(1):124-129.

Legrand-Abravanel F, Colson P, Leguillou-Guillemette H, Alric L, Ravaux I, Lunel-Fabiani F, Bouviers-Alias M, Trimoulet P, Chaix ML, Hezode C, Foucher J, Fontaine H, Roque-Afonso AM, Gassin M, Schvoerer E, Gaudy C, Roche B, Doffoel M, D'Alteroche L, Vallet S, Baazia Y, Pozzetto B, Thibault V, Nousbaum JB, Roulot D, Coppere H, Poinard T, Payan C, Izopet J. 2009. Influence of the HCV subtype on the virological response to pegylated interferon and ribavirin therapy. J Med Virol 81(12):2029-2035.

Legrand-Abravanel F, Nicot F, Boulestin A, Sandres-Saune K, Vinel JP, Alric L, Izopet J. 2005. Pegylated interferon and ribavirin therapy for chronic hepatitis C virus genotype 4 infection. J Med Virol 77(1):66-69.

Lindahl K, Stahle L, Bruchfeld A, Schvarcz R. 2005. High-dose ribavirin in combination with standard dose peginterferon for treatment of patients with chronic hepatitis C. Hepatology 41(2):275-279.

Lopez-Cortes L, Valera-Bestard B, Gutierrez-Valencia A, Ruiz-Valderas R, Jimenez L, Arizcorreta A, Terron A, Viciana P. 2008. Role of Pegylated Interferon-alpha-2a and Ribavirin Concentrations in Sustained Viral Response in HCV/HIV-Coinfected Patients. Clin Pharmacol Ther.

Loustaud-Ratti V, Alain S, Rousseau A, Hubert IF, Sauvage FL, Marquet P, Denis F, Lunel F, Cales P, Lefebvre A, Fauchais AL, Liozon E, Vidal E. 2008. Ribavirin exposure after the first dose is predictive of sustained virological response in chronic hepatitis $\mathrm{C}$. Hepatology 47(5):1453-1461. 
1 Maeda Y, Kiribayashi Y, Moriya T, Maruhashi A, Omoda K, Funakoshi S, Murakami T,

2 Takano M. 2004. Dosage adjustment of ribavirin based on renal function in Japanese patients with chronic hepatitis C. Ther Drug Monit 26(1):9-15.

Manns MP, McHutchison JG, Gordon SC, Rustgi VK, Shiffman M, Reindollar R, Goodman ZD, Koury K, Ling M, Albrecht JK. 2001. Peginterferon alfa-2b plus ribavirin compared with interferon alfa-2b plus ribavirin for initial treatment of chronic hepatitis C: a randomised trial. Lancet 358(9286):958-965.

Martin-Carbonero L, Benhamou Y, Puoti M, Berenguer J, Mallolas J, Quereda C, Arizcorreta A, Gonzalez A, Rockstroh J, Asensi V, Miralles P, Laguno M, Moreno L, Giron JA, Vogel M, Garcia-Samaniego J, Nunez M, Romero M, Moreno S, de la Cruz JJ, Soriano V. 2004. Incidence and predictors of severe liver fibrosis in human immunodeficiency virus-infected patients with chronic hepatitis C: a European collaborative study. Clin Infect Dis 38(1):128-133.

Maynard M, Pradat P, Gagnieu MC, Souvignet C, Trepo C. 2008. Prediction of sustained virological response by ribavirin plasma concentration at week 4 of therapy in hepatitis C virus genotype 1 patients. Antivir Ther 13:607-611.

McHutchison JG, Everson GT, Gordon SC, Jacobson IM, Sulkowski M, Kauffman R, McNair L, Alam J, Muir AJ. 2009. Telaprevir with peginterferon and ribavirin for chronic HCV genotype 1 infection. N Engl J Med 360(18):1827-1838.

Nicot F, Legrand-Abravanel F, Lafont T, Dubois M, Saune K, Pasquier C, Chatelut E, Izopet J. 2008. Serum concentrations of ribavirin and pegylated interferon and viral responses in patients infected with HIV and HCV. J Med Virol 80(9):1523-1529.

Nicot F, Legrand-Abravanel F, Sandres-Saune K, Boulestin A, Dubois M, Alric L, Vinel JP, Pasquier C, Izopet J. 2005. Heterogeneity of hepatitis C virus genotype 4 strains circulating in south-western France. J Gen Virol 86(Pt 1):107-114. 
1 Pearlman BL, Ehleben C, Saifee S. 2007. Treatment extension to 72 weeks of peginterferon

2

3

4 5

6

7

8

9

10 and ribavirin in hepatitis $\mathrm{c}$ genotype 1-infected slow responders. Hepatology 46(6):1688-1694.

Rauch A, Kutalik Z, Descombes P, Cai T, Di Iulio J, Mueller T, Bochud M, Battegay M, Bernasconi E, Borovicka J, Colombo S, Cerny A, Dufour JF, Furrer H, Gunthard HF, Heim M, Hirschel B, Malinverni R, Moradpour D, Mullhaupt B, Witteck A, Beckmann JS, Berg T, Bergmann S, Negro F, Telenti A, Bochud PY. 2010. Genetic variation in IL28B is associated with chronic hepatitis C and treatment failure: a genome-wide association study. Gastroenterology 138(4):1338-1345, 1345 e13311337.

Rendon AL, Nunez M, Romero M, Barreiro P, Martin-Carbonero L, Garcia-Samaniego J, Jimenez-Nacher I, Gonzalez-Lahoz J, Soriano V. 2005. Early monitoring of ribavirin plasma concentrations may predict anemia and early virologic response in HIV/hepatitis C virus-coinfected patients. J Acquir Immune Defic Syndr 39(4):401405.

Roulot D, Bourcier V, Grando V, Deny P, Baazia Y, Fontaine H, Bailly F, Castera L, De Ledinghen V, Marcellin P, Poupon R, Bourliere M, Zarski JP, Roudot-Thoraval F. 2007. Epidemiological characteristics and response to peginterferon plus ribavirin treatment of hepatitis C virus genotype 4 infection. J Viral Hepat 14(7):460-467.

Sandres-Saune K, Deny P, Pasquier C, Thibaut V, Duverlie G, Izopet J. 2003. Determining hepatitis C genotype by analyzing the sequence of the NS5b region. J Virol Methods 109(2):187-193.

Sarrazin C, Zeuzem S. 2010. Resistance to Direct Antiviral Agents in Patients With Hepatitis C Virus Infection. Gastroenterology 138(2):447-462. 
1 Simmonds P, Bukh J, Combet C, Deleage G, Enomoto N, Feinstone S, Halfon P, Inchauspe G, Kuiken C, Maertens G, Mizokami M, Murphy DG, Okamoto H, Pawlotsky JM, Penin F, Sablon E, Shin IT, Stuyver LJ, Thiel HJ, Viazov S, Weiner AJ, Widell A. 2005. Consensus proposals for a unified system of nomenclature of hepatitis $C$ virus genotypes. Hepatology 42(4):962-973.

Simmonds P, Holmes EC, Cha TA, Chan SW, McOmish F, Irvine B, Beall E, Yap PL, Kolberg J, Urdea MS. 1993. Classification of hepatitis C virus into six major genotypes and a series of subtypes by phylogenetic analysis of the NS-5 region. J Gen Virol 74 ( Pt 11):2391-2399.

Suppiah V, Moldovan M, Ahlenstiel G, Berg T, Weltman M, Abate ML, Bassendine M, Spengler U, Dore GJ, Powell E, Riordan S, Sheridan D, Smedile A, Fragomeli V, Muller T, Bahlo M, Stewart GJ, Booth DR, George J. 2009. IL28B is associated with response to chronic hepatitis $\mathrm{C}$ interferon-alpha and ribavirin therapy. Nature genetics 41(10):1100-1104.

Svensson JO, Bruchfeld A, Schvarcz R, Stahle L. 2000. Determination of ribavirin in serum using highly selective solid-phase extraction and high-performance liquid chromatography. Ther Drug Monit 22(2):215-218.

Talal AH, Ribeiro RM, Powers KA, Grace M, Cullen C, Hussain M, Markatou M, Perelson AS. 2006. Pharmacodynamics of PEG-IFN alpha differentiate HIV/HCV coinfected sustained virological responders from nonresponders. Hepatology 43(5):943-953.

Tanaka Y, Nishida N, Sugiyama M, Kurosaki M, Matsuura K, Sakamoto N, Nakagawa M, Korenaga M, Hino K, Hige S, Ito Y, Mita E, Tanaka E, Mochida S, Murawaki Y, Honda M, Sakai A, Hiasa Y, Nishiguchi S, Koike A, Sakaida I, Imamura M, Ito K, Yano K, Masaki N, Sugauchi F, Izumi N, Tokunaga K, Mizokami M. 2009. Genome- 
wide association of IL28B with response to pegylated interferon-alpha and ribavirin

2 therapy for chronic hepatitis C. Nature genetics 41(10):1105-1109.

3 Thomas F, Nicot F, Sandres-Saune K, Dubois M, Legrand-Abravanel F, Alric L, Peron JM, 4 Pasquier C, Izopet J. 2007. Genetic diversity of HCV genotype 2 strains in south 5 western France. J Med Virol 79(1):26-34.

6 Tsubota A, Hirose Y, Izumi N, Kumada H. 2003. Pharmacokinetics of ribavirin in combined 7 interferon-alpha $2 \mathrm{~b}$ and ribavirin therapy for chronic hepatitis $\mathrm{C}$ virus infection. $\mathrm{Br} \mathrm{J}$

8 Clin Pharmacol 55(4):360-367.

9 Zeuzem S. 2004. Heterogeneous virologic response rates to interferon-based therapy in 10 patients with chronic hepatitis C: who responds less well? Ann Intern Med $11 \quad 140(5): 370-381$. 
1

2

3

4

5

6

7

8

9

10

11

\section{Figure 1:}

2 (a) Serum ribavirin concentrations and (b) serum pegylated interferon alpha-2a (peg-IFN3 a2a) concentrations at week 4 (W4) and 12 (W12), according to the early virological 4 response and the sustained virological response. Data are presented as box plots in which $550 \%$ of values lie within the box. The horizontal lines through the middle of the boxes 6 represent the median values. The top and the bottom of each box are the $10^{\text {th }}$ and the $90^{\text {th }}$ 7 percentiles of all values.

8

9 Figure 2:

10 Relationship between the plasma ribavirin concentrations at weeks 4 or 12 and the 11 hemoglobin concentration at week 12. The Spearman correlation rate is indicated for data at 12 weeks 4 and 12. 